Sri Lanka J. Aquat. Sci. 12 (2007): 1-18

\title{
Performance of GIFT strain of Oreochromis niloticus in culture-based fisheries in non-perennial reservoirs, Sri Lanka
}

\author{
W.M.H.K. WIJENAY AKE, U.S. AMARASINGHE ${ }^{2} *$ AND S.S DE \\ SILV A
}

${ }^{1}$ Department of Aquaculture and Fisheries, Wayamba University of Sri Lanka, Makandura, Gonawila (NWP), Sri Lanka.

${ }^{2}$ Department of Zoology, University of Kelaniya, Kelaniya 11600, Sri Lanka.

${ }^{3}$ School of Life and Environmental Sciences, Deakin University, PO box 423, W arrnambool, Victoria 3280, Australia.

*Corresponding author (E-mail: zoousa@kln.ac.lk)

\begin{abstract}
The superiority of Genetically Improved Farmed Tilapia (GIFT) strain of Oreochromis niloticus has been demonstrated under intensive culture conditions in ponds and cages but its performance under extensive culture conditions and interactions with other cultured species, such as in culture-based fisheries, is unknown. In the present study, performance of GIFT strain in culture-based fisheries in reservoirs of Sri Lanka was evaluated on the basis of specific growth rate, survival, species interaction and biological productivity of habitat. Fourteen non-perennial reservoirs were stocked with carps and GIFT strain and fish yield of all species in the 14 reservoirs studied ranged from 53.4 to $1800.7 \mathrm{~kg} \mathrm{ha}^{-1}$, which consisted of $0 \%$ to $32 \%$ of GIFT strain. Y ield of GIFT strain varied from $0 \%$ to $188.3 \mathrm{~kg} \mathrm{ha}^{-1}$ in the 14 reservoirs. Results of the analysis indicated that biological productivity of the non-perennial reservoirs had greater influence on carp yield than on yield of GIFT strain. Also, there was no significant difference $(p>0.05)$ between mean fish yields of GIFT strain and non-GIFT strain in culture-based fisheries of non-perennial reservoirs. High variability of specific growth rate of GIFT strain is evident in culture-based fisheries in non-perennial reservoirs. The GIFT strain, which requires supplementary feeding for achieving its maximum growth potential, may be incapable of competing with other species for natural food in the non-perennial reservoirs. As such, GIFT strain is not a suitable candidate for the development of culture-based fisheries in non-perennial reservoirs of Sri Lanka.
\end{abstract}




\section{Introduction}

Tilapia is known as 'aquatic chicken' because of its herbivorous and omnivorous habit, feeding low down on the food chain in the culture systems providing a major source of protein for rural poor in Asia (Maclean 1984). Under a long-term research and development project on Nile tilapia Oreochromis niloticus (L.) conducted by the International Centre for Living Aquatic Resources Management (ICLARM; now known as the World Fish Centre) during 1988-1997, Genetically Improved Farmed Tilapia (GIFT) strain was developed using several strains of natural Nile tilapia. GIFT strain is not genetically modified or transgenic but it has been bred using traditional selective breeding methods to produce a super tilapia. This GIFT strain of Nile tilapia is considered to have superior growth qualities over the commonly cultured other strains of the same species in Asia (Eknath and Acosta 1998). As such, GIFT strain is fast becoming the most preferred and commonly used for tilapia culture in Asia (Dey et al. 2000). GIFT strain was first introduced to Sri Lanka in 2001, from the Philippines by the National Aquaculture Development Authority of Sri Lanka. The superiority of GIFT strain however, has been demonstrated under intensive culture conditions in ponds and cages (Dey et al. 2000), but its performance under extensive culture conditions and when interacting with other cultured species in culturebased fisheries, is unknown.

Culture-based fisheries development in small water bodies is recognised by most Asian countries as an appropriate strategy to increase fish production, particularly in rural areas (De Silva 2003). This development is seen as less resource intensive, is often community-based, environmentally less perturbing, and is considered to contribute significantly to poverty alleviation in rural areas in Asia (De Silva 2003; Felsing et al. 2003). In general, in most of the Asian countries, the species commonly used in culture-based fishery activities are Chinese major carps (bighead carp Aristichthys nobilis (Richardson), silver carp Hypophthalamichthys molitrix (C. et V.), grass carp Ctenopharyngodon idellus (C. et V.)), Indian major carps (rohu Labeo rohita Hamilton, mrigal Cirrhinus mrigala Hamilton), Java barb (Barbodes (=Barbonymus) gonionatus (Bleeker)) and common carp Cyprinus carpio L., in various combinations and ratios (Chakrabarthy and Samaranayake 1983; Nguyen et al. 2001 amongst others). On the other hand, there are no reports on the utilization of tilapias in culture-based fisheries, even though the consumer preference for tilapias is growing world over (V annuccini 2001; De Silva et al. 2004).

The present study, a component of a larger study (see Wijenayake et al. 2005), was conducted in 14 non-perennial reservoirs in five administrative districts located in the dry zone of the country (receiving less than $187 \mathrm{~mm}$ annual rainfall), with a large number of non-perennial reservoirs. In this study GIFT Nile tilapia was used as one of the stocking materials in combination with Chinese and Indian major carp species and performance of GIFT strain in culture-based fisheries in reservoirs was evaluated on the basis of specific 
growth rate, survival, species interaction and biological productivity of habitat.

\section{Materials and Methods}

The study was conducted in 14 randomly selected non-perennial reservoirs in the administrative districts of Anuradhapura, Kurunegala, Hambanthota, Moneragala and Rathnapura (Figure 1), chosen for their high density of non-perennial reservoirs. These reservoirs come under the jurisdiction of the Department of Agrarian Development, and day-to-day water management is handled by Farming Committees (FCs), consisting of downstream agricultural farmers. With the help of aquaculture committees, appointed by FCs in individual reservoirs, fish fingerlings were stocked in the 2002/2003 culture cycle, which extended from December 2002 until AugustOctober 2003 (Table 1).

Stocking was carried out between December 2002 and March 2003. The choice of species and stocking densities (SD) used were determined on the basis of preliminary work reported previously (Chandrasoma and Kumarasiri 1986), and a species combination (one of five; see Table 1) was assigned to each reservoir on a random basis. Initially SD was estimated on the basis of values of reservoir area given in the data book for Village Irrigation Schemes of Sri Lanka (Anon. 2000a, 2000b, 2000c, 2000d, 2000e). As data on reservoir area documented in these available sources are unrealistic, the areas at full supply level (FSL) of each reservoir were subsequently determined using Global Positioning System (GPS) (Trimble GeoExplorer G3; Trimble Navigation Ltd, California, USA). Using the new information, SD values for GIFT strain and all major carps stocked separately were then re-calculated (Table 1).

For estimation of SD, 50\% of reservoir area at FSL was taken as the effective area because extents of non-perennial reservoirs vary from area at FSL during the rainy season in November-December to zero or negligible area during the dry season.

The fingerlings stocked were common carpCyprinus carpio L., mrigal Cirrhinus mrigala Hamilton, bighead carp Aristichthys nobilis Richardson, catla Catla catla Hamilton, rohu Labeo rohita Hamilton and GIFT strain of Nile tilapia Oreochromis niloticus (L.), and the mean size at stocking of each species was $2.58 \pm 0.28,2.42 \pm 0.22,3.15 \pm 0.37,2.95 \pm 0.73$, $5.0 \pm 0.59$, and $3.0 \pm 0.49 \mathrm{~g}$, respectively.

Chlorophyll-a contents in individual reservoirs were obtained from Jayasinghe et al. (2005). 


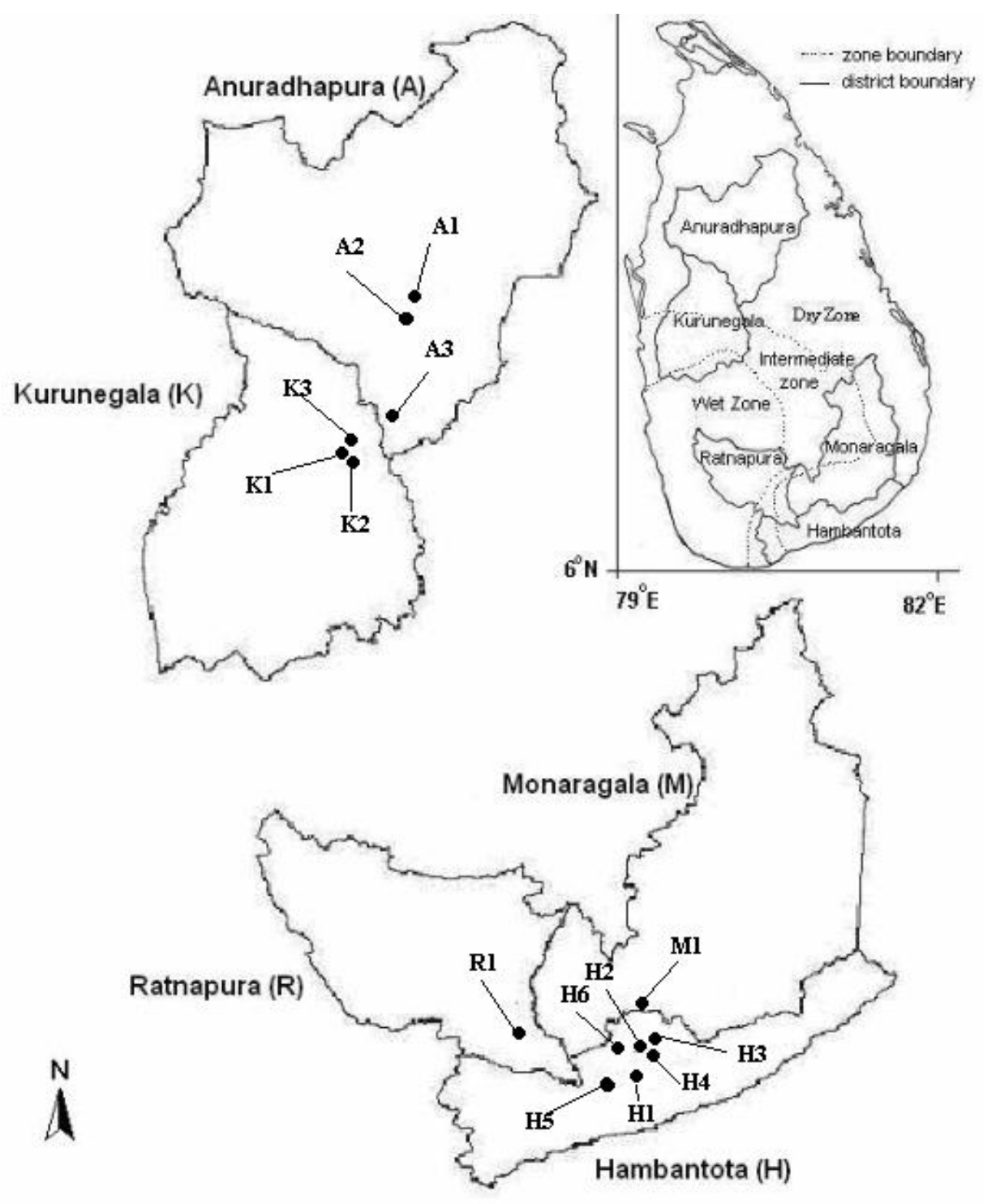

\section{$\begin{array}{llllllll}20 & 0 & 20 & 40 & 60 & 80 & 100 & \mathrm{~km}\end{array}$}

Figure 1. The climatic zones of Sri Lanka and the locations of reservoirs studied in five administrative districts. A1 - Bulankulama, A2 - Gambirigas wewa, A3 - Karabegama wewa, K1 - Kumbalporuwa wewa, K2 Wawullewa wewa, K3 - Mataluwawa wewa, H1 - Gonnoruwa wewa, H2 Kudaindi wewa, H3 - Lunuweraniya wewa, H4 - Palujandura wewa, H5 Swodagama wewa, H6 - Weli wewa, M1 - Bodagama wewa, R1 Mahagalara wewa. 
Table 1. The 14 reservoirs studied, reservoir area at full supply level, species combinations used and stocking densities.

\begin{tabular}{|c|c|c|c|c|}
\hline \multirow{2}{*}{ Reservoir } & \multirow{2}{*}{$\begin{array}{l}\text { Area at full } \\
\text { supply level } \\
\text { (ha) }\end{array}$} & \multirow{2}{*}{$\begin{array}{c}\text { Species } \\
\text { combination* }\end{array}$} & \multicolumn{2}{|c|}{$\begin{array}{l}\text { Stocking density } \\
\left(\text { Nos } \mathrm{ha}^{-1}\right)\end{array}$} \\
\hline & & & GIFT & $\begin{array}{c}\text { Major } \\
\text { carps }\end{array}$ \\
\hline Bulankulama wewa & 8.2 & I & 188.7 & 1698.3 \\
\hline Gambirigaswewa & 16.6 & II & 69.3 & 623.7 \\
\hline Karabegama wewa & 9.3 & IV & 390.2 & 3509.8 \\
\hline Kumbalporuwa wewa & 9.5 & $\mathrm{~V}$ & 259.2 & 2332.8 \\
\hline W awullewa wewa & 20.7 & II & 49.8 & 448.2 \\
\hline Mataluwawa wewa & 28.9 & II & 49.0 & 441.0 \\
\hline Gonnoruwa wewa & 22.4 & III & 21.8 & 196.2 \\
\hline Kudaindi wewa & 13.4 & III & 68.0 & 612.0 \\
\hline Lunuweraniya wewa & 10.8 & II & 136.4 & 1227.6 \\
\hline Palujandura wewa & 4.9 & II & 193.6 & 1742.4 \\
\hline Svodagama wewa & 3.2 & III & 196.3 & 1766.7 \\
\hline Weli wewa & 5.7 & II & 51.4 & 462.6 \\
\hline Bodhagama wewa & 13.4 & III & 145.9 & 1313.1 \\
\hline Mahagalara wewa & 8.9 & III & 112.9 & 1016.1 \\
\hline
\end{tabular}

\footnotetext{
*Species combinations

I - 30\% Common carp \& mrigal; 30\% Bighead carp/Catla; 30\% Rohu; 10\% GIFT

II - 30\% Common carp; 30\% Bighead carp/Catla; 30\% Rohu; 10\% GIFT

III - 40\% Common carp; 30\% Bighead carp/Catla; 20\% Rohu; 10\% GIFT

IV - 20\% Common carp; 40\% Bighead carp/Catla; 30\% Rohu; 10\% GIFT

V - 20\% Common carp \& mrigal; 40\% Bighead carp/Catla; 30\% Rohu; 10\% GIFT
} 
Harvesting was carried out using a seine net $(62 \mathrm{~m}$ length; $8.5 \mathrm{~m}$ height; $5 \mathrm{~cm}$ stretch mesh size) with the help of the aquaculture committees, as the water level in the reservoirs start receding from about June/July. Several reservoirs were completely harvested within one day but most reservoirs were harvested over a period of 7-14 days. All fish harvested were separated into species, bulk weight $(\mathrm{kg})$ of each species was determined using a field balance, and a random sample of each species was taken for measuring weight (to the nearest $1 \mathrm{~g}$ ). Similarly, the weights of naturally-recruited species were also determined.

Specific growth rate (SGR) of stocked species; was calculated as:

$\mathrm{SGR}=\left[\left(\mathrm{Ln} \mathrm{W}_{2}-\mathrm{Ln} \mathrm{W}_{1}\right) /\right.$ Culture period in days $] \times 100$

where, $\mathrm{W}_{1}=$ initial body weight in $\mathrm{g}, \mathrm{W}_{2}=$ final body weight in $\mathrm{g}$.

SGR of each species was compared to obtain the best performing species in the culture-based fisheries systems.O. niloticus (non-GIFT strain) yield data of culture-based fisheries in 14 culture trials in non-perennial reservoirs of Sri Lanka (Ms. K.B.C. Pushpalatha, pers. comm.) were compared with the yields of GIFT strain reported in the present study for the Ln $(\mathrm{Y}+1)$ transformed data using Student's t-test.

Various regression relationships (i.e. linear, curvilinear and secondorder) were computed to investigate the relationships of the total yield to \%carps in yield, \%tilapia in yield, \%snakeheads in yield and chlorophyll-a content of the reservoirs. Relationships of stocking densities of carps and GIFT strain and their yields were also determined. Mean SGR of GIFT strain stocked in the present study were compared with GIFT strain and non-GIFT strain of Nile tilapia in different culture systems in various localities using box-plots.

\section{Results}

Total fish catch consisted of the fish species stocked and naturally recruited indigenous species (Table 2). In some reservoirs, percentage return of Oreochromis niloticus was over $100 \%$ possibly due to the reason that the yield consisted of non-GIFT strain ofO. niloticus, which were recruited from the wild through associated waterways or due to spawning of stocked tilapias. As it was difficult to differentiate GIFT and non-GIFT strains of $O$. niloticus morphologically, allO. niloticus (hereafter referred to as tilapia) harvested were considered as GIFT strain.O. mossambicus was also caught in some reservoirs and as $O$. mossambicus was not stocked in any of the reservoirs studied, they were obviously recruited from the wild through associated waterways. O. mossambicus was included in the category of other species which also included Anabas testudineus, Etroplus suratensis, Mystus keletius, Puntius sarana and Trichogaster pectoralis. 
Table 2. Yield of the species stocked ( $\mathrm{kg} \mathrm{hä})$, snakeheads and other naturally recruited species. For the yield estimates, $50 \%$ of area at the full supply level was considered as the effective area for fish culture. Other species includelnabas testudineus, Etroplus suratensis, Mystus keletius, Oreochromis mossambicus, Puntius sarana and Trichogaster pectoralis. Reservoirs marked with asterisks had $>100 \%$ recovery rates of $O$. niloticus either due to recruitment from associated water way or due to spawning of the fish stocked. Ns - Reservoirs not stocked with the species

\begin{tabular}{|c|c|c|c|c|c|c|c|c|c|}
\hline Reservoir & $\begin{array}{c}\text { Common } \\
\text { carp }\end{array}$ & Mrigal & $\begin{array}{l}\text { Bighead } \\
\text { carp }\end{array}$ & Catla & Rohu & Tilapia & Snakehead & Other spp. & Total \\
\hline Bulankulama wewa* & 34.3 & 31.8 & 3.8 & 43.9 & 100.7 & 102.6 & 35.0 & 0.4 & 352.5 \\
\hline Gambirigas wewa & 28.6 & Ns & Ns & 11.9 & 54.3 & 0.8 & 31.5 & 0 & 127.1 \\
\hline Karambegama wewa* & 9.9 & Ns & 1.3 & 12.6 & 16.4 & 1.6 & 11.6 & 0 & 53.4 \\
\hline Kumbalporuwa wewa* & 5.0 & 32.2 & 1.5 & 23.3 & 123.7 & 1.4 & 17.9 & 0 & 205.0 \\
\hline Wavullewa wewa & 7.7 & Ns & 0 & 1.9 & 38.5 & 38.5 & 33.0 & 0.7 & 120.3 \\
\hline Mataluwawa wewa* & 3.1 & Ns & 2.2 & 0 & 27.8 & 0 & 21.7 & 1.9 & 56.7 \\
\hline Gonnoruwa wewa & 8.1 & Ns & 20.1 & Ns & 14.5 & 11.6 & 0 & 0.3 & 54.6 \\
\hline
\end{tabular}

Table 2 Continued. 
Table 2. Continued from page 7

\begin{tabular}{|c|c|c|c|c|c|c|c|c|c|}
\hline Reservoir & $\begin{array}{l}\text { Common } \\
\text { carp }\end{array}$ & Mrigal & $\begin{array}{l}\text { Bighead } \\
\text { carp }\end{array}$ & Catla & Rohu & Tilapia & Snakehead & Other spp. & Total \\
\hline Kudaindi wewa* & 12.5 & Ns & 356.2 & Ns & 1.6 & 6.4 & 0 & 0.5 & 377.2 \\
\hline Lunuveraniya wewa* & 89.3 & Ns & 420.5 & Ns & 12.4 & 188.3 & 0 & 0 & 710.5 \\
\hline Palujadura wewa* & 71.1 & Ns & 117.1 & Ns & 74.1 & 13.0 & 0 & 0.6 & 275.3 \\
\hline Svodagama wewa & 162.3 & Ns & 1167.8 & Ns & 312.4 & 157.7 & 0 & 0.5 & 1800.7 \\
\hline Weli wewa & 103.8 & Ns & 151.1 & Ns & 27.3 & 90.8 & 0 & 0 & 373.0 \\
\hline Bodhagama wewa & 99.5 & Ns & 409.9 & Ns & 52.4 & 62.1 & 0 & 0 & 623.9 \\
\hline Mahagalara wewa & Ns & Ns & Ns & 560.4 & 150.2 & 166.5 & 0 & 0 & 877.1 \\
\hline
\end{tabular}


(a)

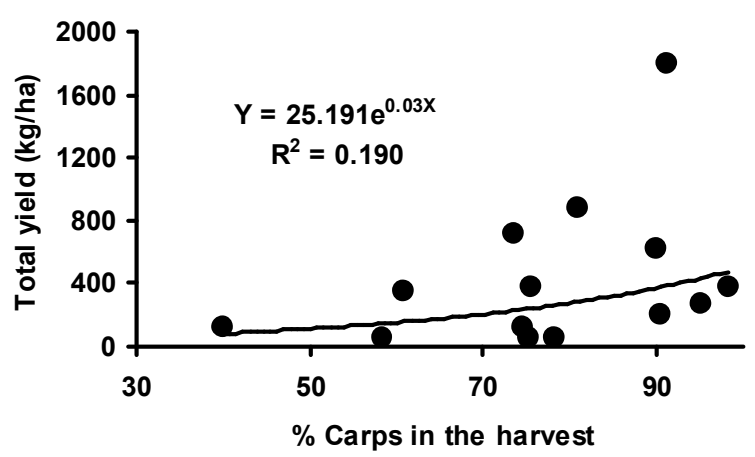

(b)

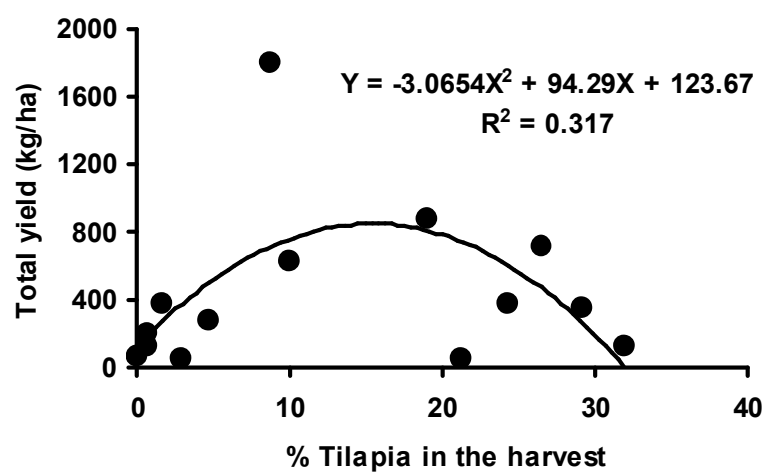

(c)

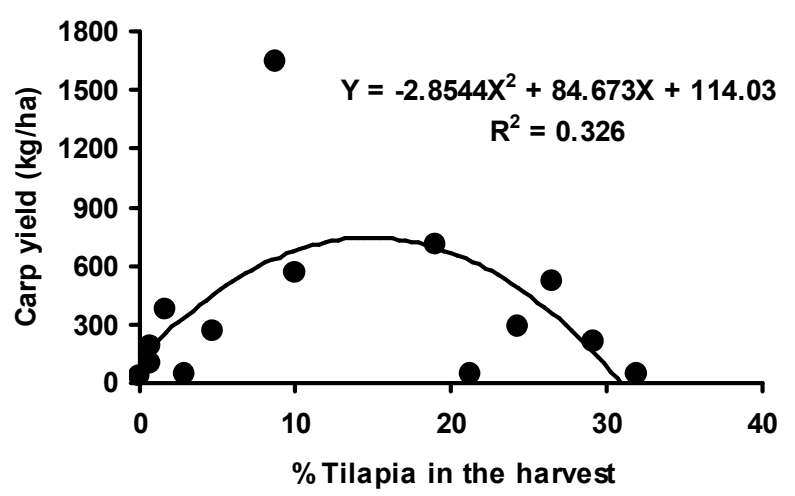

Figure 2. Relationships between (a) percentage carps in the harvest and total yield, (b) percentage tilapia in the harvest and total yield, and (c) percentage tilapia in the harvest and yield of carps. 
Fish yield of all species in the 14 reservoirs studied ranged from 53.4 to $1800.7 \mathrm{~kg} \mathrm{ha}^{-1}$, which consisted of $0 \%$ to $32 \%$ of tilapia. Tilapia yield varied from $0 \%$ to $188.3 \mathrm{~kg} \mathrm{ha}^{-1}$ in the 14 reservoirs (Table 2). Carp yields in the 14 reservoirs were much higher than tilapia yield and ranged from 33.1 to $1642.5 \mathrm{~kg} / \mathrm{ha}$ (Table 2). The exponential relationship between total yield and percentage carps in the harvest in the 14 reservoirs (Figure 2a) also indicates the significant influence of proportion of carps in the harvest on total yield. There were second order, positive polynomial relationships between percentage tilapia in the harvest and total yield (Figure $2 b$ ) and carp yield (Figure 2c), with declining trends in yield when the proportion of tilapia in the harvest exceeded $15 \%$.

In some reservoirs studied, snakeheads (Channa striata) were present in the harvest. As such, it is thought that one of the reasons for low yields of some species is due to predatory pressure by snakeheads. Total yield, carp yield as well as tilapia yield are found to be negatively influenced by the proportion of snakeheads in the harvest (Figures 3a-c). Other species in the harvest (A. testudineus, E. suratensis, M. keletius, O. mossambicus, $P$. sarana and $T$. pectoralis), which formed an insignificant proportion of the harvest, did not have any influence on total yield (Figure 3d).

The relationships of chlorophyll-a content with tilapia yield (Fig. 4a) and with carp yield (Figure $4 \mathrm{~b}$ ) indicate that biological productivity of the non-perennial reservoirs has greater influence on carp yield than on tilapia yield.

The positive second order relationship between SD of carps and carp yield (Figure 5a) indicates that the optimal SD of carps producing the maximum yield in non-perennial reservoirs is about 1968 fingerlings per ha. However, a significant relationship is not evident between SD of GIFT strain and tilapia yield in the same reservoirs (Figure 5b).

Mean fish yields $( \pm$ Standard Error) of GIFT strain (14 culture trials; present study) and non-GIFT strain (14 culture trials; Ms. K.B.C. Pushpalatha, pers. comm.) of $O$. niloticus in culture-based fisheries trials in non-perennial reservoirs of Sri Lanka, t-value and significance level are shown in Table 3. These results indicate that there is no significant difference $(p>0.05)$ between mean fish yields of GIFT strain and non-GIFT strain in culture-based fisheries of non-perennial reservoirs.

Box plot of SGR of GIFT strain and non-GIFT strain in culture-based fisheries in non-perennial reservoirs of Sri Lanka, pond and cage culture systems (Lazard et al. 1988; Dey et al. 2000) in different localities is shown in Figure 6. This indicates that SGR of GIFT strain in non-perennial reservoirs shows high variability compared to those of the same strain in other culture systems such as pond and cage culture. From the Figure 6, it is also evident that non-GIFT strain of $O$. niloticus has not performed well in the culture-based fisheries in non-perennial reservoirs either compared to its culture performance in other culture systems. 
(a)

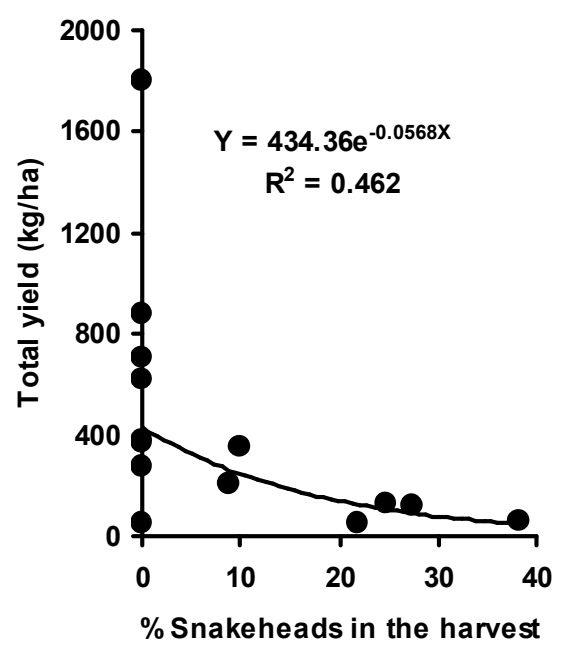

(c)

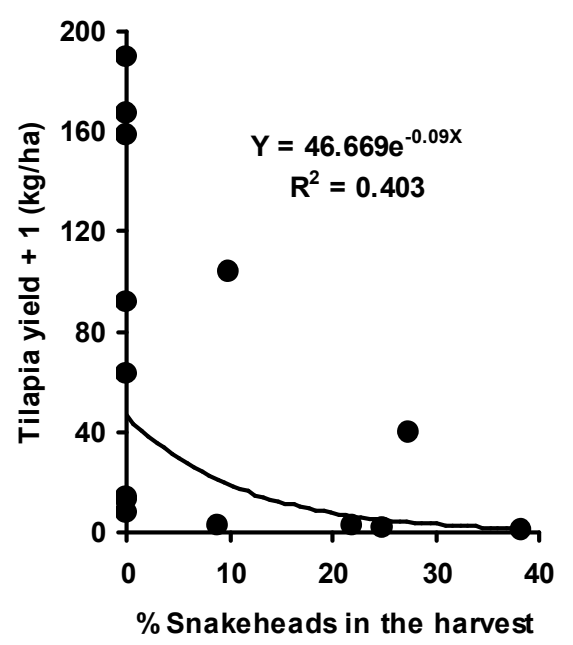

(b)

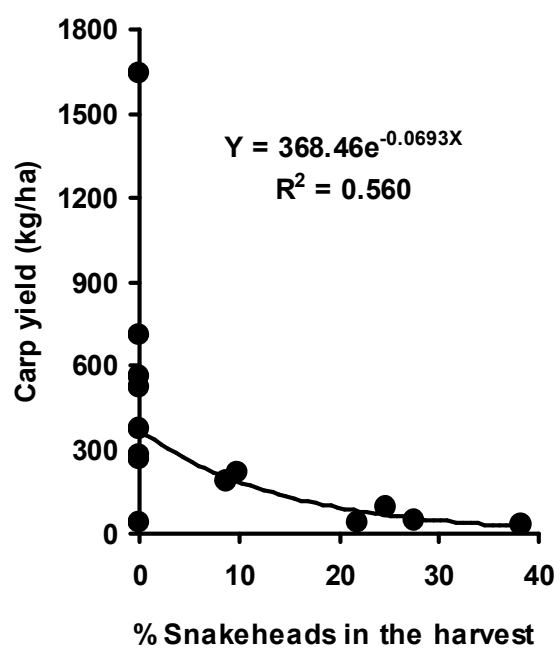

(d)

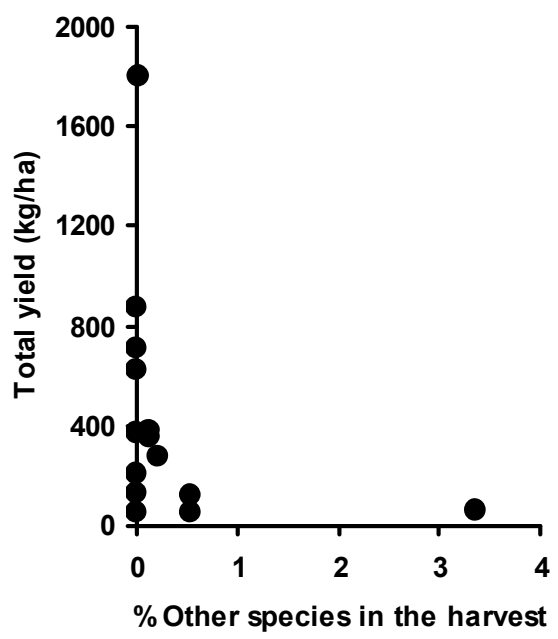

Figure 3. Relationships between (a) percentage snakeheads in the harvest and total yield, (b) percentage snakeheads in the harvest and yield of carps, (c) percentage snakeheads in the harvest and yield of GIFT strain ofO. niloticus, and (d) percentage other species in the harvest and total yield. 
(a)

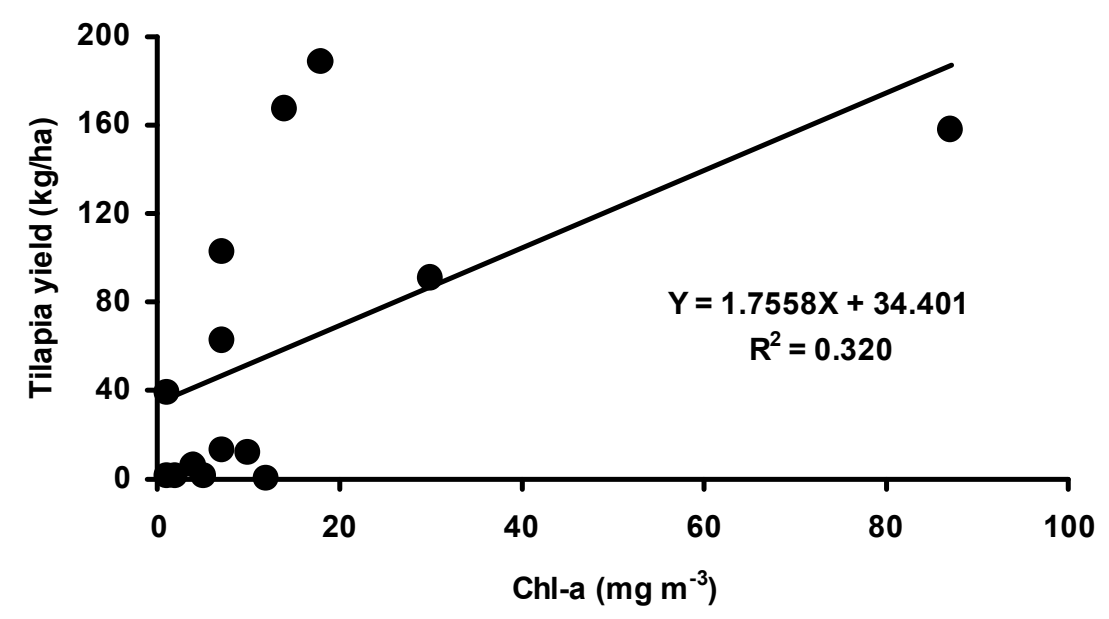

(b)

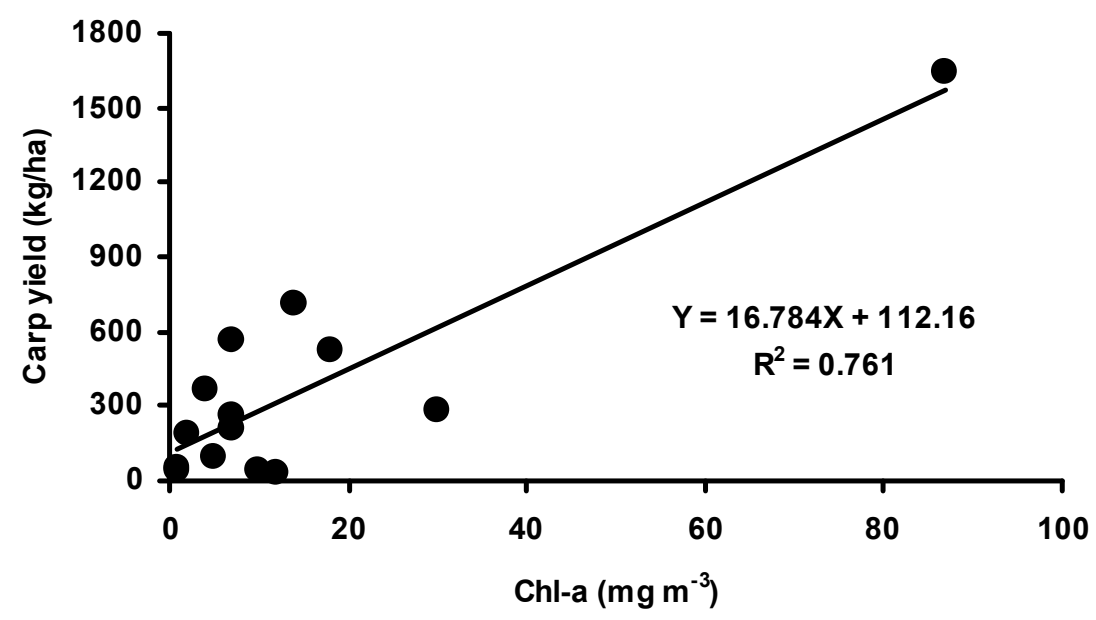

Figure 4. Relationships between chlorophyll-a content and (a) yield of carps and (b) yield of tilapia in non-perennial reservoirs of Sri Lanka. 
(a)

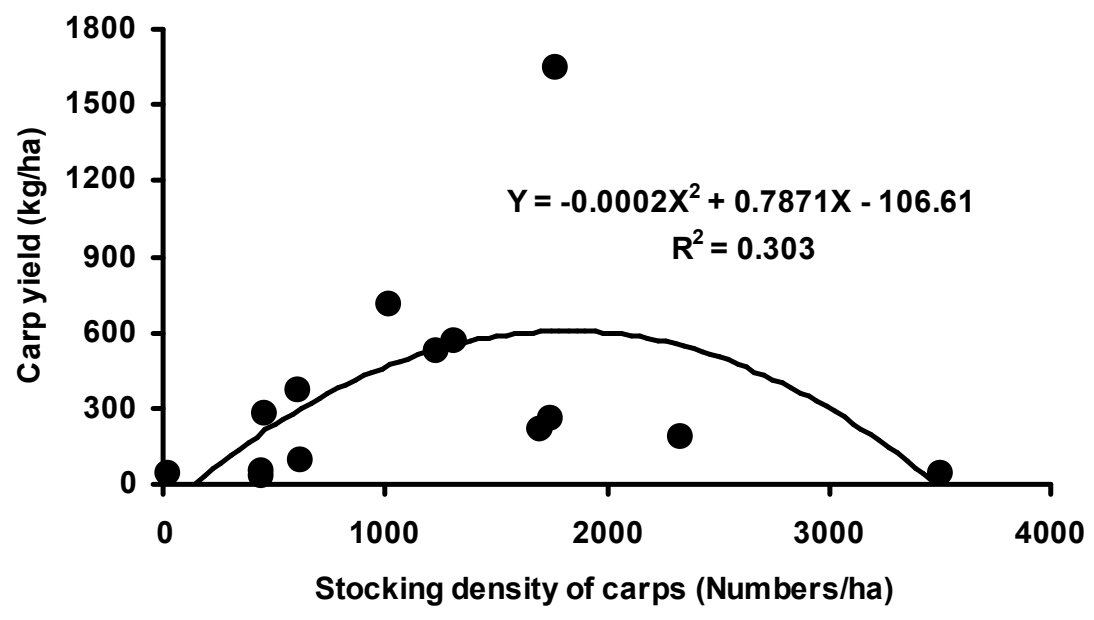

(b)

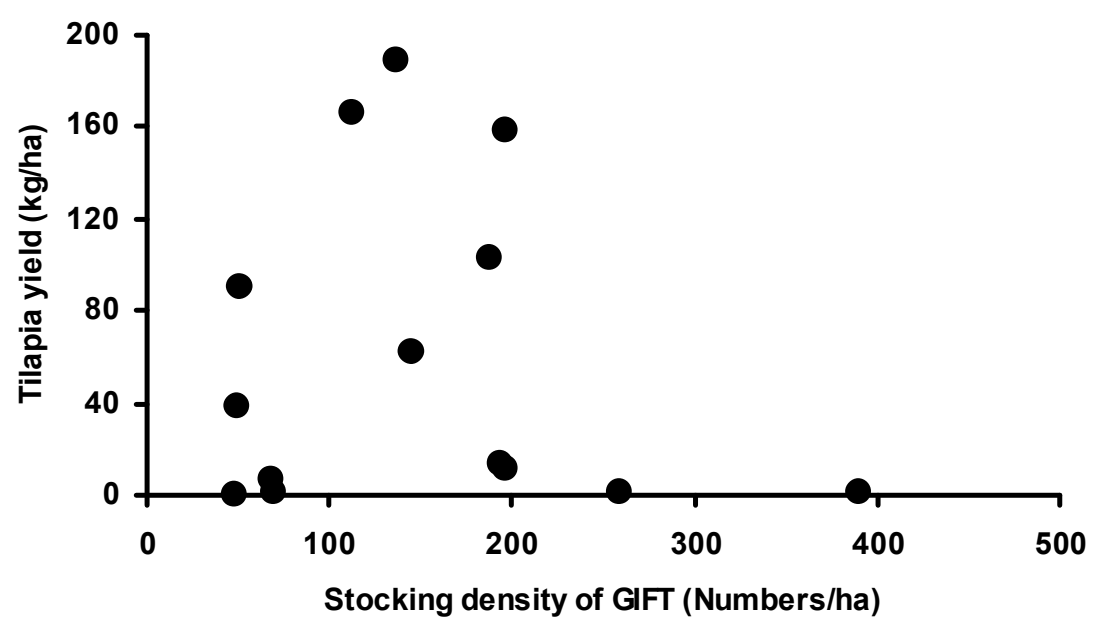

Figure 5. Relationships between (a) stocking density of carps and yield of carps, and (b) stocking density of GIFT strain of O. niloticus and tilapia yield. 


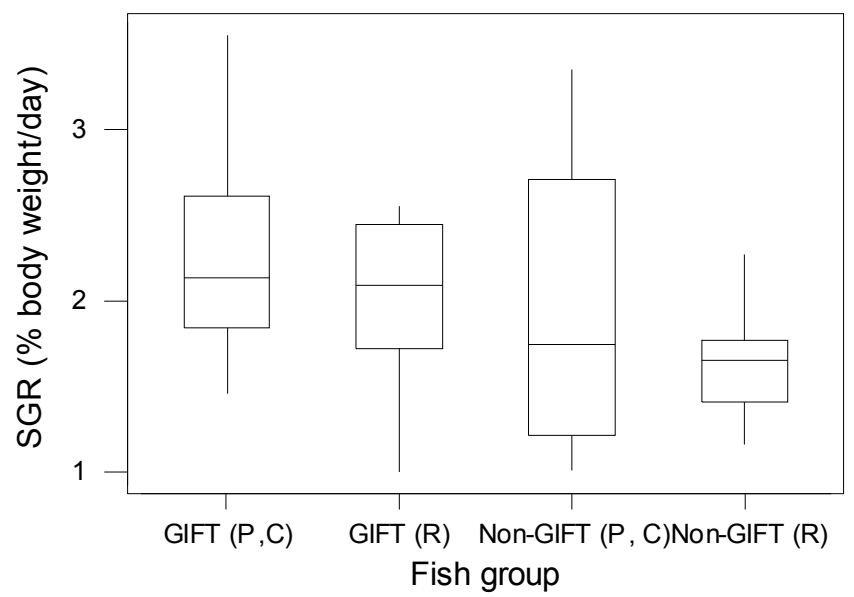

Figure 6. Box-plot of SGR of GIFT strain in 07 pond and cage aquaculture systems [GIFT (P, C); Data from Dey et al. 2000], in culture-based fisheries in 14 non-perennial reservoirs of Sri Lanka [GIFT (R); present study], in 09 pond and cage aquaculture systems [Non-GIFT (P, C); Data from Lazard et al. 1988; Dey et al. 2000] and non-GIFT strain of $O$. niloticus in 14 nonperennial reservoirs of Sri Lanka [Non-GIFT (R); Data from Ms. K.B.C. Pushpalatha, unpublished].

\section{Discussion}

With increased understanding of the biology and genetics, allied with improvements in aquaculture management, tilapias, most notablyO. niloticus and certain hybrids, have become very important farmed species (Penman and McAndrew 2000). De Silva et al. (2004) pointed out that tilapias have made a significant contribution to food production, poverty alleviation and livelihood support in Asia and the Pacific region. GIFT strain ofO. niloticus is a product of carefully conducted genetic selection and improvement strategy based on parent fish collected from four African countries (Egypt, Ghana, Kenya and Senegal) and four commercialO. niloticus strains from Israel, Singapore, Taiwan and Thailand (Eknath et al. 1993; Dey and Gupta 2000). The GIFT strain has been shown to perform better than other strains of O. niloticus in pond and cage culture systems (Dey et al. 2000).

In spite of the importance of tilapias in aquaculture (Fritzsimmons 1997; Fritzsimmons and Filho 2000), culture-based fisheries systems, which are labeled as an underutilized opportunity for fisheries development (De Silva 2003), are widely based on stocking and recapture of hatchery-reared 
Chinese and Gangetic major carps. Well-developed induced breeding techniques coupled with larval and juvenile rearing method of major carps and disrepute of tilapias due to its feature of stunting in natural and quasinatural water bodies are some of the major reasons for using major carps in culture-based fisheries.

Table 3. Mean fish yields $( \pm \mathrm{SE})$ of GIFT strain and non-GIFT strain of $O$. niloticus in 28 culture-based fisheries trials in non-perennial reservoirs of Sri Lanka, t-value for $\mathrm{Ln}(\mathrm{Y}+1)$ transformed data and statistical significance level.

\begin{tabular}{lc}
\hline Description & Value \\
\hline Mean yield of GIFT strain $(\mathrm{kg} / \mathrm{ha})$ & 60.1 \\
Mean yield of non-GIFT strain $(\mathrm{kg} / \mathrm{ha})$ & 48.6 \\
Ln [mean yield +1$]( \pm \mathrm{SE})$ of GIFT strain & $3.38 \pm 0.50$ \\
Ln [mean yield +1$]( \pm \mathrm{SE})$ of non-GIFT & $3.00 \pm 0.30$ \\
strain & \\
t-value & 0.655 \\
Significance level & 0.52 \\
\hline
\end{tabular}

As evident from the present study too, exotic carps play a significant positive role in achieving high fish yields in the culture-based fisheries in non-perennial reservoirs of Sri Lanka. It was observed that presence of GIFT strain in high densities reduced performance of exotic carps in these culturebased fisheries systems. As predatory pressure by piscivore, Channa striata (Figure 3) is common to all prey species (carps, GIFT and others), less performance of major carps in reservoirs with high proportions of GIFT strain in the harvest might be due to inter-specific competition between carps and tilapias. Furthermore, the present analysis indicates that the natural biological productivity, measured as chlorophyll-a content in non-perennial reservoirs, is more efficiently utilized by exotic carps than GIFT strain of $O$. niloticus.

One can argue that the poor performance of GIFT strain in terms of yield produced, compared to major carps, can be due to low stocking densities of GIFT strain stocked in the non-perennial reservoirs (Table 1). However, the relationship of SD and yield in GIFT strain is not statistically significant and in fact, at stocking densities higher than 200 fingerlings per ha, GIFT yield is insignificant, possibly due to the reason that density dependent factors negatively influence fish yield. Lorenzen (1996) also has shown that in culture-based fisheries systems, density dependent growth is a crucial factor in achieving optimal fish yields. The significant positive second order relationship between SD and yield of carps on the other hand, indicates that they are capable of thriving on natural food resources in the nonperennial reservoirs. There seems to be an optimal level of SD (1968 fingerlings per ha) in carps, possibly due to the density-dependent factors 
influencing fish yields (Figure 5). This apparent optimal stocking density of carps is much higher than the apparent optimal SD of GIFT (around 100 fingerlings per ha; Figure 5b).

High variability of SGR of GIFT strain in non-perennial reservoirs may be due to the presence of non-GIFT strain ofO. niloticus in the harvest, which has recruited from the associated waterways. However as a whole, low SGR recorded indicates that GIFT strain did not perform well in the culturebased fisheries compared to other culture systems such as ponds and cages.

The primary objective of developing GIFT strain ofO. niloticus was to produce a strain of superior growth performance in aquaculture systems. Although, there are some common features in aquaculture systems and culture-based fisheries systems, the latter does not depend on supplementary feeding but natural food items in the habitat. The GIFT strain, which requires supplementary feeding for achieving its maximum growth potential, seems to be incapable of competing with other species for natural food in the nonperennial reservoirs. Results of the present study therefore indicate that GIFT strain is not a suitable candidate for stocking for the development of culturebased fisheries in non-perennial reservoirs of Sri Lanka. As there has been an emerging emphasis for the development of culture based fisheries in tropical regions (Welcomme and Bartley 1998; De Silva, 2003) and for the popularization of GIFT strain of O. niloticus (www.worldfishcenter.org), these findings would be useful for planning culture-based fisheries development.

\section{Acknowledgements}

The study was funded by the Australian Centre for International Agricultural Research (Project No. FIS 2001/030). We are thankful to the farmer organizations of villages in five districts for their support. Thanks are also due to Ms. K.B.C. Pushpalatha (NAQDA, Sri Lanka) for providing unpublished data on SGR of O. niloticus in 14 non-perennial reservoirs of Sri Lanka.

\section{References}

Anon. 2000a.

Data Book for Village Irrigation Schemes of Sri Lanka Anuradhapura District. Ministry of Agriculture and Lands, Department of Agrarian Services, Colombo. 247 pp.

Anon. 2000b.

Data Book for Village Irrigation Schemes of Sri Lanka - Hambantota

District. Ministry of Agriculture and Lands, Department of Agrarian Services, Colombo. 70 pp. 
Anon. 2000c.

Data Book for Village Irrigation Schemes of Sri Lanka - Kurunegala District. Ministry of Agriculture and Lands, Department of Agrarian Services, Colombo. 381 pp.

Anon. 2000d.

Data Book for Village Irrigation Schemes of Sri Lanka - Moneragala

District. Ministry of Agriculture and Lands, Department of Agrarian Services, Colombo. 90 pp.

Anon. 2000e.

Data Book for Village Irrigation Schemes of Sri Lanka - Ratnapura

District. Ministry of Agriculture and Lands, Department of Agrarian Services, Colombo. 151 pp.

Chandrasoma, J. \& W.S.A.A.L. Kumarasiri 1986.

Observations on polyculture of fish in seasonal tanks in Sri Lanka.

Journal of Inland Fisheries, Sri Lanka 3: 49-55.

Chakrabarty, R.D. \& R.A.D.B. Samaranayaka 1983.

Fish culture in seasonal tanks in Sri Lanka. Journal of Inland

Fisheries, Sri Lanka 2: 125-140.

Dey, M.M., A.E. Ekanath, S. Li, M.G. Hussain, T.M. Thien, V.H. Nguyen, S. Aypa \& N. Pongthana 2000.

Performance and nature of genetically improved farmed tilapia. Aquaculture Economics and Management 4: 83-106.

Dey, M.M. \& M.V . Gupta 2000.

Socioeconomics of disseminating genetically improved Nile tilapia in Asia: an introduction. Aquaculture Economics and Management 4: 511.

De Silva, S.S. 2003.

Culture-based fisheries: an underutilized opportunity in aquaculture development. Aquaculture 221: 221- 243.

De Silva, S.S., R. Subasinghe, D.M. Bartley \& A. Lowther 2004.

Tilapias as alien aquatics in Asia and the Pacific: a review. FAO Fisheries Technical Paper No. 453: 65 pp.

Eknath, A.E. \& B.O. Acosta 1998.

Genetic Improvement of Farmed Tilapias (GIFT) Project: Final Report, March 1988 to December 1997. International Center for Living Aquatic Resources Management, Manila.

Eknath, A.E., M.M. Tayamen, M.S. Palada-de Vera, J.C. Danting, R.A. Reyes, J.B. Capili, H.L. Bolivar, T.A. Abella, A.V. Circa, H.B. Bentsen, B. Gjerde, T. Gjedrem \& R.S.V. Pullin 1993.

Genetic improvement of farmed tilapias: the growth performance of eight strains of Oreochromis niloticus tested in different farm environments. Aquaculture 111: 171-188.

Felsing, M., G. Haylor, G. Dutta, B. Kumar, S. Shweta, A. Natarajan, G. Arora \& V. Singh 2003.

Carp production in seasonal water bodies in eastern India. Asian Fisheries Science 16: 1-5. 
Fitzsimmons, K. (Ed.) 1997.

Tilapia Aquaculture. Proceedings of the Fourth International Symposium on Tilapias in Aquaculture. 9-12 November 1997.

Northeast Regional Agricultural Engineering Service, Ithaca.

Fitzsimmons, K. \& J.C. Filho (Eds) 2000.

Tilapia Aquaculture in the $2 \mathrm{P}^{\mathrm{st}}$ Century. Proceedings from the Fifth

International Symposium on Tilapia Aquaculture. 3-7 September 2000, V olume 2. Panorama da Aquicultura, Rio de Janeiro.

Jayasinghe, U.A.D., U.S. Amarasinghe \& S.S. De Silva 2005.

Trophic classification of non-perennial reservoirs utilized for the development of culture-based fisheries, Sri Lanka. International Reviews of Hydrobiology90: 209-222.

Lorenzen, K. 1996.

A simple von Bertalanffy model for density-dependent growth in extensive aquaculture, with an application to common carp Cyprinus carpio). Aquaculture 142: 191-205.

Lazard, J., P. Morissens \& P. Parrel 1988.

Artisanal aquaculture of Tilapia in west Africa: Comparative analysis of different culture systems and their level of development. In: R.S.V. Pullin, T. Bhukaswan, K. Tonguthai and J.L. Maclean (eds) The Second International Symposium on Tilapia in Aquaculture, Bangkok, Thailand. 41-52 pp. ICLARM Conference Proceeding 15. Department of Fisheries, Bangkok, Thailand and the International Center for Living Aquatic Resources Management, Manila, Philippines.

Maclean, J.L. 1984.

Tilapia: The aquatic chicken. ICLARM Newsletter (Manila) 7(1): 17.

Nguyen, H.S., T.A. Bui, T.L. Le, T.T.T. Nguyen \& S.S. De Silva 2001.

The culture-based fisheries in small, farmer-managed reservoirs in two provinces of northern Vietnam; an evaluation based on three production cycles. Aquaculture Research 32: 975-990.

Penman, D.J. \& B.J. MacAndrew 2000.

Genetics for the management and improvement of cultured tilapias. In: Beveridge, M.C.M. and MacAndrew B.J. (eds) Tilapias: Biology and Exploitation. 227-266 pp. Kluwer Academic Publishers, Dordrecht, The Netherlands.

Vannuccini, S. 2001.

Global markets for tilapia. INFOFISH International 6/2001: 16-21.

Welcomme, R.L. \& D.M. Bartley 1998.

Current approaches to the enhancement of fisheries. Fisheries Management and Ecology 5: 351-382

Wijenayake, W.M.H.K., U.A.D.Jayasinghe, U.S. Amarasinghe, J.A. Athula, K.B.C. Pushpalatha \& S.S. De Silva 2005.

Culture-based fisheries in non-perennial reservoirs in Sri Lanka:

Production and relative performance of stocked species. Fisheries Management and Ecology 12: 249-258. 